\section{The Teaching of Physics to Engineering Students.}

THE American Physical Society recently set up a committee to consider and report on special problems and difficulties in the teaching of physics, and the first report issued by the committee, prepared by Prof. A. W. Duff of the Worcester Polytechnic, Mass., deals with the teaching of physics to students of engineering. It summarises the opinions expressed by a large number of teachers and engineers in replies to a long list of questions addressed to them by the committee. All agree that the object of a physics course is to provide the student with a sound knowledge of the fundamental principles on which engineering depends, and that he should be shown how these principles find their application in common experiences of everyday life, so that at a later stage his knowledge of principles should be in a form immediately available for the solution of new practical problems. He must acquire the habit of searching for the principles underiying a mass of phenomena and of drawing safe conclusions from those principles. Lectures should be well thought out and the matter presented in clear form.

Some teachers think the class should be required to prepare sections of the text-book for repetition or for discussion in class, although this is felt by many to be a school method not desirable in engineering colleges. The problems set for exercise should be of a practical nature and not deteriorate into numerical substitution in a formula. Laboratory work is essential, but too great a degree of precision of results should not be demanded, the object of the work being to elucidate principles rather than attain a high order of accuracy. The relative importance of the objects to be attained in teaching physics to engineers is considered to be-first, the scientific habit of thought; second, knowledge of the laws of physics; third, initiative and ingenuity; fourth, knowledge of facts and methods; and, fifth, accurate observation.

The evidence as to present teaching in America shows that physics gets the proper proportion of time only in the best engineering colleges, and that in all cases it suffers from the inability to reason logically which most boys display on leaving school. The diversity of symbols used for the same quantity by different writers, and the difference between the engineering and scientific units, are two further difficulties under which the subject labours. A great majority of the teachers and engineers consulted were in favour of establishing a journal dealing with new instruments, methods and experiments, recent research, applications of physics, and the theory of teaching.

\section{University and Educational Intelligence.}

Belfast-Dr. R. C. Gray, a graduate of the University of Glasgow, has been appointed lecturer in physics in the Queen's University.

CAMBRIDGE.- It is proposed to create a University lectureship in crystallography for Mr. A. Hutchinson, Pembroke College.

A revised report on draft ordinances for the admission of women to the titles of degrees has been presented by the Syndicate appointed to prepare them. The chief modifications proposed are (I) that research students shall be supernumerary to the limit of 500 imposed on the number of women students receiving instruction in the University; (2) that a woman candidate for honours, who fails to qualify for an honours degree and is " allowed the Ordinary " shall be qualified for the title of a degree; (3) that women students be allowed to enter for pass examinations in agriculture or in architecture so long as there are no Tripos examinations in these subjects. The scale of fees has been revised in view of criticisms raised at the discussion on the first report. The Syndicate makes it clear that it is not proposed to introduce a Regulation formally admitting women to instruction in the University. It is preferred to assume that the present practice of admitting women will be continued.

LEEDs.-Applications are invited for the professorship of chemistry shortly to be vacant by the resignation of Prof. Smithells. The salary is to be $1200 l$. per annum, and the appointment will take effect on October I, I923. Applications for the post are to be sent to the Registrar, who will supply further information if desired.

London. - An assistant lecturer in Physical Chemistry is required at University College, at a yearly salary of $300 l$. Physicists possessing a knowledge of chemistry, as well as chemists, are eligible for the post. Applications, accompanied by testimonials, record of degrees, published work, and teaching experience (if any), must reach the Secretary of the College by, at latest, Wednesday, December 20.

ACCORDING to a report prepared during the month of August for the League of Nations on "The condition of intellectual life in Austria," the professional classes and all who depend for their livelihood on intellectual work have, since the revolution of 1918 , sunk into a position in which they form, in an economic sense, the lowest stratum of the community, their work being invariably worse paid than manual labour. Their physical and mental powers are consequently being sapped by insufficiency of food, and their numbers are being reduced by actual starvation. Among the organisations whereby they are striving to protect their common interests is a Central Council of Austrian Intellectual Workers, having its seat at the University of Vienna, and associated with this is an "office for providing books and instruments." This body is endeavouring to establish agreements with associations in other countries whereby second-hand or surplus books and periodicals may be obtained under conditions ensuring their fullest possible utilisation and providing for the determination of the value of Austrian books offered in exchange. One such agreement has been concluded with the Universities Library and Student Relief for Europe affiliated to the Universities Committee, Imperial War Relief Fund, General Buildings, Aldwych, W.C.2. Through this committee the universities of the United Kingdom have, during the past two years, contributed substantially towards relieving the necessities of professors and students of Austrian as well as other European universities. It is now urgently soliciting further help in money or in kind.

THE setting-up in I9I8 of the standing committee of Vice-Chancellors and Principals was one of the most noteworthy events in the long history of the universities of the United Kingdom. Up to that date each university had been a law unto itself, formulating its own policy and drafting its own ordinances with little regard for the needs or the doings of the others, save in a few matters which could only be handled by the universities collectively, such, for example, as an appeal to the Chancellor

NO. 277 I, VOL. IIO] 